\title{
Pneumomediastinum as a complication of COVID-19 disease: A case report
}

\author{
Betül ikbal DOĞAN ${ }^{\mathbf{1}}$ (ID) \\ Ceyda MAHLEÇ \\ $\operatorname{ANAR}^{2}(I D)$ \\ Bünyamin \\ SERTOĞULLARINDAN ${ }^{1}$ \\ (ID) \\ Muzaffer Onur \\ TURAN $^{1}($ ID)
}

Cite this article as: Doğan Bi, Mahleç Anar C, Sertoğullarından B, Turan MO. Pneumomediastinum as a complication of COVID-19 disease: A case report. Tuberk Toraks 2021;69(1):94-97.

\section{Yazışma Adresi (Address for Correspondence)}

\section{Dr. Betül İkbal DOĞAN}

İzmir Katip Çelebi Üniversitesi, Göğüs Hastalıkları Anabilim Dalı, IZMIR - TÜRKIYE

e-mail: betuldogan1993@hotmail.com

CCopyright 2021 by Tuberculosis and Thorax.

Available on-line at www.tuberktoraks.org.com
${ }^{1}$ Department of Chest Diseases, İzmir Katip Çelebi University, İzmir, Turkey

${ }^{1}$ izmir Katip Çelebi Üniversitesi, Göğüs Hastalıkları Anabilim Dalı, izmir, Türkiye

${ }^{2}$ Clinic of Chest Diseases, İzmir Atatürk Training and Research Hospital, İzmir, Turkey

${ }^{2}$ İzmir Atatürk Eğitim ve Araştırma Hastanesi, Göğüs Hastalıkları Kliniği, Izmir, Türkiye

\section{ABSTRACT}

Pneumomediastinum as a complication of COVID-19 disease: A case report As the COVID-19 pandemic progresses, awareness of uncommon presentations of the disease increases. Such is the case with pneumomediastinum. Recent evidence has suggested that these can occur in the context of COVID19 pneumonia, even in the absence of mechanical ventilation-related barotrauma. We present a patient with COVID-19 pneumonia complicated by pneumomediastinum.

Key words: COVID-19; pneumomediastınum; dispnea; chest pain

ÖZ

COVID-19 hastalığının bir komplikasyonu olarak pnömomediastinum: Bir olgu sunumu

COVID-19 salgınında vaka sayısı arttıkça, hastalığın nadir görülen komplikasyonları da ortaya çıkmaya başladı. Pnömomediastinum da bunlardan biridir. Son kanıtlar, bunların COVID-19 pnömonisi sonucunda mekanik ventilasyonla ilişkili barotravma olmasa bile meydana gelebileceğini gösterdi. Biz de COVID19 enfeksiyonu sonrası pnömomediastinum gelişen bir olguyu sunuyoruz.

Anahtar kelimeler: COVID-19; pnömomediastinum; dispne; göğüs ağrısı

\section{INTRODUCTION}

Both pneumothorax and pneumomediastinum are known complications of mechanical ventilation due to intubation $(1,2)$. Nonetheless, even without barotrauma involved, pneumothorax or pneumomediastinum, or more rarely both, can be present in the context of COVID-19 $(3,4)$. Radiology stands as a cornerstone in the management of the COVID-19 pneumonia, especially in diagnosis and surveillance. 
Many parenchymal and extra-parenchymal abnormalities due to the novel coronavirus SARS-COV-2 have been described on CT. Parenchymal lesions are both alveolar and interstitial. The presentation on CT depends on the evolution in time of the pathology. Indeed, the most frequent and early manifestation is parenchymal ground glass opacities. The occurrence of spontaneous pneumomediastinum is an uncommon presentation. Herein, we report a case who had spontaneous pneumomediastinum related to COVID19 pneumonia and discuss with the literature.

\section{Case}

A 26-year-old male patient was admitted to the emergency room with a 3-day history of dyspnea and chest pain. The patient had not reported any previous lung pathology. It was learned that he had a smoking history of 5 packs for years and had no additional disease. Breathing sounds were normal on physical examination. On presentation, his temperature was $37.4^{\circ} \mathrm{C}$. Laboratory tests showed a C-reactive protein concentration of $106.3 \mathrm{mg} / \mathrm{dL}$ (normal range $0-5 \mathrm{mg}$ /
dL). Complete blood count showed elevated leukocytes (12450 cells per $\mu \mathrm{L}$ [normal range 3500-9500 cells per $\mu \mathrm{L}]$ ), neutrophils (6900 cells per $\mu \mathrm{L}$ [20006500 cells per $\mu \mathrm{L}$ )), and eosinophil (690 cells per $\mu \mathrm{L}$ [100-500 cells per $\mu \mathrm{L}]$ ), while the lymphocyte count (3000 cells per $\mu \mathrm{L}$ ) and D-dimer value $(210 \mathrm{ng} / \mathrm{mL}$ ) were in the normal range. Other laboratory values were within the normal range. Arterial blood gas revealed with an $\mathrm{SO}_{2}$ of $94 \%$ and $\mathrm{PaO}_{2} 80 \mathrm{mmHg}$. RT-PCR analysis of the sputum samples resulted positive for SARS-CoV-2. A chest CT scan showed multiple ground-glass opacities in the upper and lower lobes of both lungs (Figures 1a, 1b, 1c ) In the mediastinum, the presence of free air around the vascular structures, trachea, main bronchi was observed. It was evaluated as pneumomediastinum. (Figures 2a, $2 b, 2 c)$. The patient had no history of trauma. Interventional intervention was not considered for the patient who was consulted with thoracic surgery. A conservative management was chosen because the pneumomediastinum was very small. The patient received favipiravir for COVID-19 pneumonia and
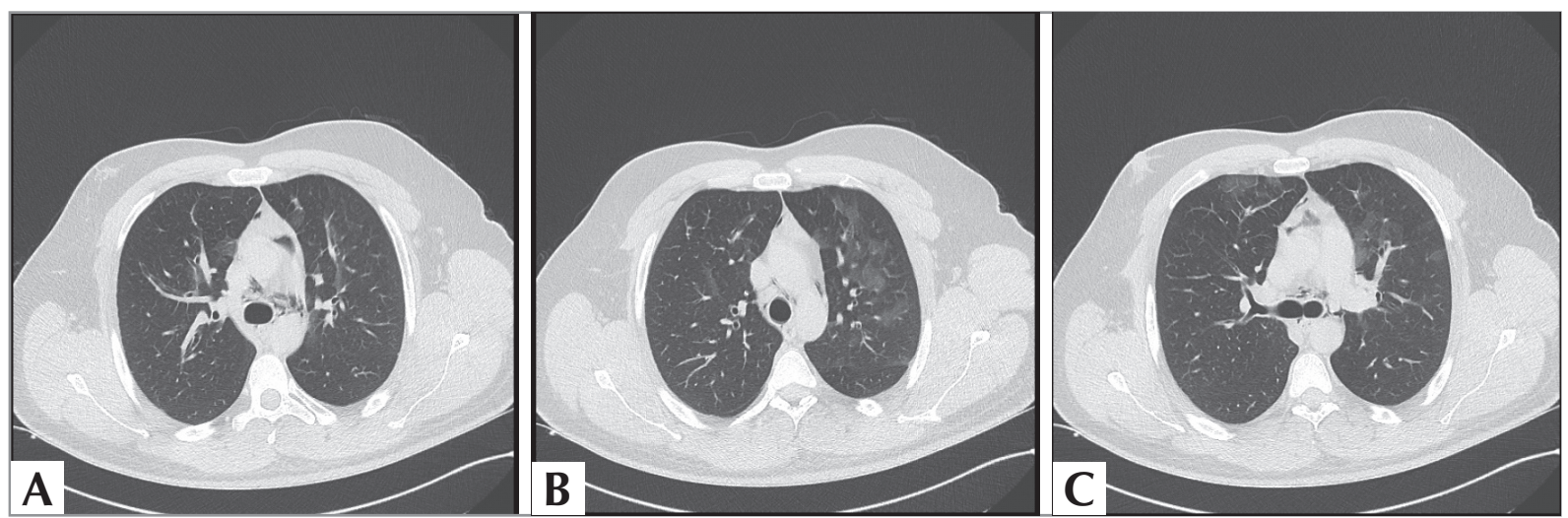

Figure 1. Ground glass areas of COVID-19 pneumonia in Thorax CT parenchyma sections.
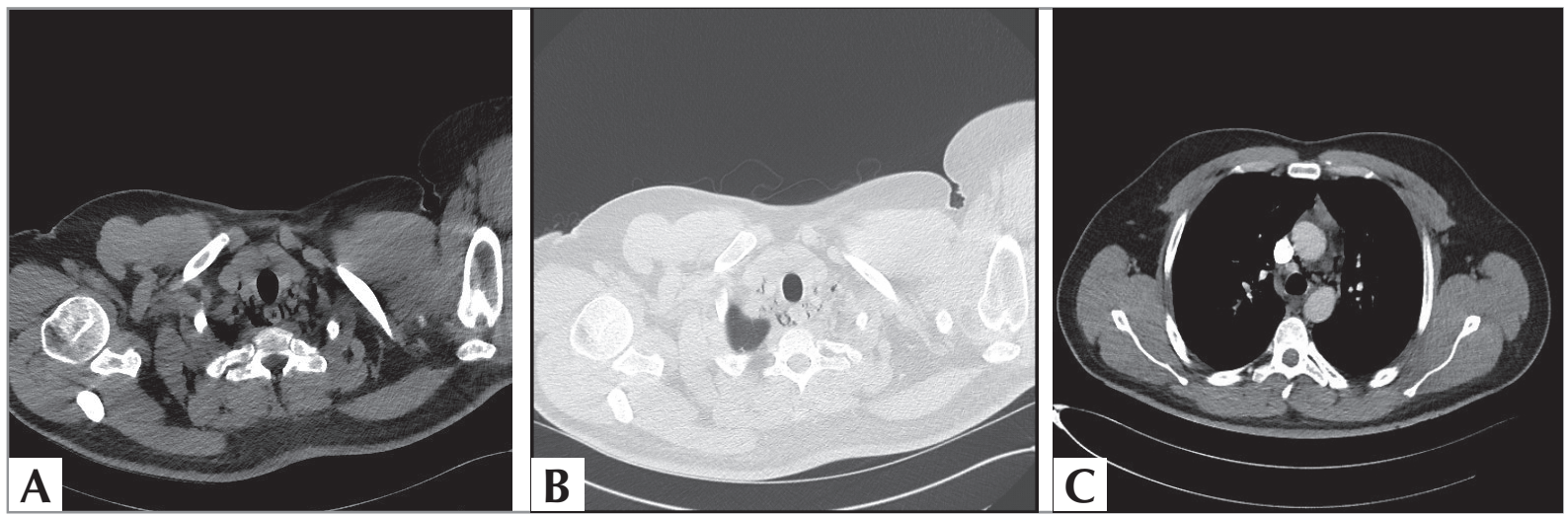

Figure 2. Pneumomedastinum areas in mediastinum and parenchyma sections of Thorax CT. 
oxygen inhalation therapy for 5 days. The patient, whose dyspnea regressed during hospitalization, was discharged at his own request to come for control.

\section{DISCUSSION}

COVID-19 is a new disease caused by a coronavirus SARS-CoV-2. The viral particles can easily reach the pulmonary terminal structure, such as the alveolar wall and the interlobular septum, which cause an early alveolar exudation and a lymphocytic infiltration in the pulmonary interstitium. The most common clinical manifestations are fever, cough, myalgia or fatigue. Other symptoms are diarrhea, nausea, headache and hemoptysis (5). When pneumothorax and pneumomediastinum cases associated with COVID19 have been examined in a review (6), of the pneumomediastinum cases, male sex is the most affected $(66.6 \% ; 4 / 6)$, and only $33.3 \%(2 / 6)$ present any associated comorbidities. In $83.3 \%$ (5/6), fever has been reported as the most frequent symptom, and one patient did not present any symptoms. Our patient dyspnea and chest pain applied with complaints.

On a chest $\mathrm{CT}$, the most characteristic findings are ground-glass opacities, consolidated opacities, and septa thickening. The lessions are located in the posterior lower lobe and in the subpleural regions (5). Pleural effusion and lymphadenopathy have been rarely described. Spontaneous pneumomediastinum (SPM) is an uncommon presentation of COVID-19. SPM is defined as by the presence of air in the mediastinum without evident causes - traumatic, iatrogenic, hollow organ perforation, surgery, gas producing infections. Our patient had no trauma and intubation history. Therefore, the pathophysiology underlying spontaneous pneumomediastinum may be secondary to alveolar damage from the infection and a rupture of the alveolar wall due to increased pressure from pronounced coughing that occurs in response to the virus. Pneumomediastinum may be due to air leakage through the interstitial space due to increased pressure (7).

P. Dionísio et al. have found that precipitating factors for a spontaneous pneumomediastinum present in $86.7 \%$ of cases, including coughing bouts, excessive tobacco use, inhalation of other drugs and varnishes, strenuous physical activity and emesis. Their patients had at least one predisposing factor, such as active cigarette smoking, recent respiratory infection, asth- ma or interstitial lung disease (8). In our case, there was no underlying diseases. Also, he did not have a history of smoking or clear parenchymal patterns that suggest bullae or emphysema that could be predisposing factors for the development of pneumothorax. Viral pulmonary infections are rarely associated with SPM. It has been sparsely reported in influenza infections (9-11). The pathophysiology that have been discussed in those cases are the increasing of alveolar pressure through coughing and eventual alveolar damage. It has been shown that not only the influenza virus-related pneumomediastinum case, but also the new SARS-CoV-2 virus causes SPM (4,12-14). In a review, in $50 \%$ of the pneumomediastinum cases, the risk factors have not been reported. The evolution was favorable in $50 \%$ of the cases (6).

The mechanism underlying pneumomediastinum in our case cannot be explained. Our patient had no triggering or predisposing factors for spontaneous pneumomediastinum and showed very few symptoms. In addition, there were only a few localized parenchymal lesions on CT. He completely recovered during his follow-up and did not experience any complications. Spontaneous pneumomediastinum is mostly a benign, self-limiting disease. The treatment approach is based on rest, oxygen therapy, and analgesia. A preparatory or accelerating factor must be managed. The association of pneumomediastinum with COVID-19 does not require special treatment. However, it should be considered as a potential aggravating factor, especially in extensive pulmonary lesions.

In conclusion, spontaneous pneumomediastinum is not a common picture in COVID-19 infection and can potentially be an aggravating factor in the treatment of COVID-19 pneumonia. Indeed, the association of a widespread parenchymal lesion in the pneumomediastinum and CT indicates severe destruction of the alveolar membrane and thus potentially worsening clinical outcomes. On the other hand, when lung lesions are not large, as in our patient's case, the clinical course and prognosis seem better.

\section{CONFLICT of INTEREST}

The authors reported no conflict of interest related to this article. 


\section{AUTHORSHIP CONTRIBUTIONS}

Concept/Design: BiD, CMA

Analysis/Interpretation: All of authors

Data Acquisition: BID, CMA

Writing: BID, CMA

Critical Revision: All of authors

Final Approval: BID, CMA

\section{REFERENCES}

1. Yao W. Emergency tracheal intubation in 202 patients with COVID-19 in Wuhan, China: lessons learnt and international expert recommendations. Br J Anaesth 2020; 125: e28-e37.

2. Jacobi A, Chung M, Bernheim A, Eber C. Portable chest $X$-ray in coronavirus disease-19 (COVID-19): a pictorial review. Clin Imaging 2020; 64: 35-42.

3. Salehi S, Abedi A, Balakrishnan S, Gholamrezanezhad A. Coronavirus disease 2019 (COVID-19): a systematic review of imaging findings in 919 patients. AJR Am J Roentgenol 2020; 215: 87-93.

4. Zhou C, Gao C, Xie Y, Xu M. COVID-19 with spontaneous pneumomediastinum. Lancet Infect Dis 2020; 510.

5. $Z u Z Y$, Jiang MD, Xu PP. Coronavirus disease 2019 (COVID-19): a perspective from China. Radiology 2020; 200490.
6. Quincho-Lopez A, Quincho-Lopez DL, Hurtado-Medina FD. Case Report: Pneumothorax and pneumomediastinum as uncommon complications of COVID-19 pneumonia-literature review Am J Trop Med Hyg 2020; 103(3): 1170-6.

7. Park SJ, Park JY, Jung J, Park SY. Clinical manifestations of spontaneous pneumomediastinum. Korean J Thorac Cardiovasc Surg 2016; 49(4): 287-91.

8. Dionísio P, Martins L, Moreira S, Manique A, El Correia I, Bárbara C. Spontaneous pneumomediastinum: a 10 years' experience of a pulmonology ward. Eur Respir J 2015; 46: 4323.

9. Park SY, Kim MG, Kim EJ. Spontaneous pneumomediastinum, pneumothorax, and subcutaneous emphysema complicating H1N1 Virus infection. Korean I Med 2011; 80 (Suppl 2).

10. Luis BAL, Navarro AO, Palacios GMR. Pneumomediastinum and subcutaneous emphysema associated with influenza A (H1N1) virus. Lancet Infect Dis 2017; 17: 671.

11. Singh BP, Shetty GS, Vijayan PA. Management of pneumomediastinum associated with H1N1 pneumonia: a case report. J Crit Care Med 2019; 5(1): 28-33.

12. Kolani S, Nawfal H, Haloua M, Lamrani YA, Boubbou M, Serraj $M$, et al. Spontaneous pneumomediastinum occurring in the SARS-COV-2 infection. 2020; 21: e00806.

13. Mohan V, Tauseen RA. Spontaneous pneumomediastinum in COVID-19. BMJ Case Rep 2020; 13: 1-2.

14. Wang W, Gao R, Zheng Y, Jiang L. COVID-19 with spontaneous pneumothorax, pneumomediastinum and subcutaneous emphysema. J Travel Med 2020. 